\title{
Ecological aspects of filling of worked-out area during underground coal mining
}

\author{
Volodymyr Buzylo ${ }^{1}$, Artem Pavlychenko ${ }^{2 *}$, and Olena Borysovska ${ }^{2}$ \\ ${ }^{1}$ Dnipro University of Technology, Department of Mining Engineering and Education, \\ 19 Yavornytskoho Ave., 49005, Dnipro, Ukraine \\ ${ }^{2}$ Dnipro University of Technology, Department of Ecology and Environmental Protection \\ Technologies, 19 Yavornytskoho Ave., 49005, Dnipro, Ukraine
}

\begin{abstract}
The ecological consequences of underground coal mining and the mechanisms of transformation of the rock mass and the earth's surface are determined. To increase the efficiency of environmental activities of coal mining enterprises, the expediency of introducing the technology of stowing of the worked-out areas with grouting solutions using rock from dumps, ash, waste from coal processing plants is substantiated. The implementation of the proposed technological solutions will ensure the protection of land, buildings and structures from under-mining, as well as improve the environmental situation in coal mining regions.
\end{abstract}

\section{Introduction}

The coal industry is the basis for the sustainable functioning of the national economy and its energy security [ $1-5]$. Underground coal mining is accompanied by a complex negative impact on all components of the environment [6-9]. In most cases, the development of coal deposits in Ukraine is carried out by obsolete and worn-out mine fund in difficult mining and geological conditions [7-12]. Chronic underfunding of coal mine greening programs leads to significant changes in the ecological status of their areas [13-18]. In terms of environmental impact, the coal industry predominates among other industries, having a detrimental effect on surface and groundwater, soil, subsoil and landscape $[17-21]$.

Coal mining in the country lasts more than 200 years, so in the coal-mining regions there is deformation of the earth's surface, flooding and salinization of land, pollution of groundwater and surface water, exacerbating socio-economic problems and forming depressed areas [17, 19, $22-24]$.

Subsidence of the earth's surface is another problem that is not taken into account when operating and closing mines. In mining regions, a large area of land to some extent affected by the negative effects of subsidence and local relief changes: the formation of man-made lakes, physical destruction of buildings and structures, damage to infrastructure, waterlogging of agricultural lands, flooding of settlements, etc. [24 - 28].

* Corresponding author: pavlichenko.a.v@nmu.one 
Prospects for the development of coal mining in different countries are ambiguous and depend on many factors: geological reserves, mining and geological conditions, the level of profitability of coal mining, the place and role of coal in the fuel and energy balance, environmental constraints, the degree of economy integration in regional and global structures. Coal mining has become profitable only in those enterprises where there were favourable mining and geological conditions or mining technologies were used with minimal impact on the environment, including the use of coal gasification methods [29-35].

The coal industry is the key to the successful establishment of Ukraine's energy independence, but at the same time it provokes a number of problems that inevitably accompany the extraction of minerals. At the same time, there are almost no long-term programs and projects aimed at the inevitable future liquidation of enterprises that would guarantee environmentally friendly decommissioning of mines. Thus, for increase of ecological safety of functioning of the coal mining enterprises it is recommended to introduce technological schemes of working off of coal seams with a stowing of the worked-out area.

\section{The research problem setting}

Long-term coal mining has led to significant changes in the stability of rocks and the earth's surface in the coal-mining regions of Ukraine. The main reasons for such changes are [36-43]:

- increase cracking and decrease the strength of rocks;

- stratification and hanging of rocks in the marginal parts of workings;

- the presence of voids in the stope workings;

- changes in hydro- and gas conductivity, hydrodynamic structure of groundwater, formation of local and general depression funnels;

- large-scale subsidence of the earth's surface;

- the presence of a significant number of vertical and inclined workings with access to the earth's surface, which are eliminated at different times and with different quality;

- under-mining of a significant number of buildings, structures and infrastructure.

The most complex transformations occur during mining operations in conditions of geological disturbances (folded rocks bedding and the presence of fractured tectonic displacements in the under-mined mass), as well as during the development of steep seams. Under such circumstances, there is an abnormal development of displacement processes, which causes significant changes in the state of the environment, waterlogging of lands and degradation of agricultural lands [44-47].

The issue of development of shifts at different stages of the life cycle of a coal mine is important for [48 - 50]:

- establishing the moment of cessation of the impact of coal mining technologies on the stability of the rock mass;

- identification of the beginning of the processes of rock mass activation caused by the subsequent liquidation of the coal mining enterprise.

The development of the process of deformation and subsidence of the earth's surface begins immediately after the lowering of the roof over the worked-out areas. The subsidence rate of the earth's surface depends on the thickness of the seam, the method of roof control, the speed of advance of the face, as well as the position of a particular point in the shift trough [36-43].

At present, a significant number of cases of surface failures under buildings and industrial facilities in areas previously mined-out by workings have been recorded in most coal mining areas [44-50]. 
The presence of a significant number of storage ponds of mine water, tailings and sludge storages and other infiltration feeding facilities in coal-mining regions leads to a steady rise in groundwater levels and the development of the process of flooding. This is due to increased filtration of man-made pollution from surface accumulators of solid and liquid waste, as well as the interaction of zones of geochemical soil contamination.

The main factors that necessitate the use of stowing of the worked-out area in coal mines are:

- protection of land, buildings and structures from under-mining;

- increasing the stability of the side rocks in the working space of the face;

- increasing the stability of development workings in order to reuse them;

- utilization of rock from carrying out development mine workings.

The need to use the technology of extraction works with the stowing can be caused by one or more of these factors.

\section{Assessment of the environmental consequences of the operation of coal mines}

Coal mining by mines (and later in the development of reserves and their elimination) increases the impact of mining on the environment due to factors such as: flooding and waterlogging of areas because of rising groundwater levels, as well as salinization of soils; change of river runoff modules; emergence of new and restoration of old extinct springs with water of increased mineralization; man-made impact on the state of the earth's surface, natural and other objects; change of engineering and geological conditions (occurrence of landslides, development of ravines, etc.); change of seismic resistance of the rock mass; pollution of atmospheric air, water bodies and soils, etc.

To date, a significant amount of research has been conducted to identify environmental impacts on environmental components arising from the operation of certain technologies and processes $[51-56]$. At the same time, there is a need for comprehensive identification of environmental and man-made consequences of subsidence of the earth's surface, flooding and waterlogging of agricultural lands, release of mine gases on the earth's surface, catastrophic environmental changes, etc. that occur during coal mining [57 - 59]. For effective management of environmental safety in coal-mining regions, there is a need to develop criteria that will most adequately characterize the levels and consequences of environmental damage in the territories of coal-mining regions.

To identify the types and sources of environmental hazards that occur at different stages of field development, the intensity and frequency of occurrence and consequences of the impact of technological processes of coal mines on the state of the environment are analysed in points: 0 -no impact; 1 - minimal or indirect impact; 2 -periodic direct or indirect impact; 3 -continuous direct impact. The results of expert environmental assessment of the consequences of the operation of coal enterprises are given in Table 1.

As a result of the analysis of table 1 it's obvious, that the activity of the coal mine has a negative impact on almost all components of the environment. Atmospheric air has the least negative impact, the source of pollution of which is mainly waste heaps.

In this case, during coal mining there are: violation of the dynamic and chemical regimes of the hydrosphere; flooding of the earth's surface in conditions of watering rock mass; activation of rock thickness shift processes disturbed by repeated under-mining during water saturation; change of physical and mechanical properties of bases of buildings and constructions at soaking of soils; intensification of gas evolution, etc. Given the significant negative impact of coal mining processes on the stability of the mountain massif, there is a need to justify ways to minimize these effects. 
Table 1. Expert assessment of environmental and man-made consequences of the operation of coal mines.

\begin{tabular}{|l|c|c|c|c|c|}
\hline \multicolumn{1}{|c|}{ Types of influence } & \multicolumn{5}{|c|}{ Objects of influence } \\
\cline { 2 - 6 } & Atmosphere & Hydrosphere & Lithosphere & Soils & Biota \\
\hline $\begin{array}{l}\text { Decreased stability and } \\
\text { hardness of rocks }\end{array}$ & 0 & 2 & 3 & 2 & 1 \\
\hline Deformation of the rock mass & 0 & 3 & 3 & 3 & 3 \\
\hline $\begin{array}{l}\text { Subsidence of the earth's } \\
\text { surface }\end{array}$ & 0 & 3 & 3 & 3 & 3 \\
\hline $\begin{array}{l}\text { Water-saturation of the rock } \\
\text { mas }\end{array}$ & 0 & 3 & 3 & 2 & 2 \\
\hline $\begin{array}{l}\text { Violation of the hydrological } \\
\text { regime }\end{array}$ & 0 & 3 & 3 & 3 & 2 \\
\hline Depletion of aquifers surface water & 0 & 3 & 2 & 3 & 2 \\
\hline $\begin{array}{l}\text { Pollution of } \\
\text { bodies }\end{array}$ & 2 & 2 & 2 & 2 & 2 \\
\hline Migration of pollutants & 0 & 3 & 1 & 2 & 2 \\
\hline $\begin{array}{l}\text { Mixing of mine waters with } \\
\text { drinking waters of } \\
\text { underground horizons }\end{array}$ & 0 & 3 & 3 & 3 & 3 \\
\hline $\begin{array}{l}\text { Flooding and waterlogging of } \\
\text { lands }\end{array}$ & 1 & 1 & 3 & 3 & 2 \\
\hline $\begin{array}{l}\text { Allocation of land for waste } \\
\text { heaps }\end{array}$ & 3 & 1 & 3 & 3 & 2 \\
\hline $\begin{array}{l}\text { Deformation and destruction } \\
\text { of buildings } \\
\text { infrastructure and }\end{array}$ & 1 & 2 & 2 & 2 \\
\hline $\begin{array}{l}\text { Formation of explosive } \\
\text { methane-air mixtures }\end{array}$ & 3 & 2 & 2 \\
\hline $\begin{array}{l}\text { Emission of mine gases to the } \\
\text { earth's surface }\end{array}$ & 3 & 2 & 2 & 2 \\
\hline
\end{tabular}

\section{Requirements to technological schemes of working off of seams with a stowing}

To increase the efficiency of environmental activities of coal mining enterprises, it is recommended to introduce the technology of stowing of the worked-out area. As materials for preparation of grouting solutions it is supposed to use rock from dumps, ashes, wastes of concentrators, etc.

When stowing of the worked-out area in order to prevent dangerous subsidence of the earth's surface, the main purpose is to ensure the maximum density of the filling mass. This requirement is especially important for the conditions of the mines of the Western Donbas, where subsidence of the earth's surface reaches significant values. Increasing the density of the filling mass can be achieved through the use of stowing materials with high compression properties by adding, for example, to the mine rock $25-30 \%$ sand; the use of the embedded pipeline with the end release of the rock or the side outlet with a slight deviation of the trajectory of the stowing material from the axis of the pipeline; the correct choice of the distance between the releases of the rocks, the optimal irrigation parameters. The filling mass should not have voids and if possible, should occupy all the worked-out area between the roof and the sole. 
An important requirement to ensure minimal subsidence of the earth's surface is also to reduce the convergence of lateral rocks in the working space of the long face. The magnitude of the convergence of the side rocks, proportional to the width of the working space, so it is necessary to bring as close as possible to the face of the formation of the filling mass and ensure the timeliness of its construction.

Studies have shown that when the roof is fully filed, the stability of the side rocks in the working space of the long face increases, in many cases the load on the mechanized support is reduced. Therefore, a full stowing in the mines of the Western Donbas is technically feasible to use, primarily in the development of formations in difficult mining and geological conditions.

The projects of the mines of the Western Donbas did not envisage the construction of stowing complexes, so it is quite difficult to lower and transport the filling materials from the surface to the breakade face without reconstruction of the mines. In addition, the "tails" of the enrichment are significantly waterlogged and cannot be used as filling material without prior drying.

Taking into account the experience of domestic coal mining enterprises, it will be expedient to equip underground precinct crushing and embedding stations, using rock as a filling material from development workings and rock cuts in long faces.

Development workings in the considered area are carried out on coal with a notch of lateral rocks. Therefore, in order to use rocks as filling material, it is necessary to separate coal from them. This requirement can be achieved by separate transportation of coal to the surface, and overburden - to the crushing-embedded complex, as well as the use of continuous and combined development systems in the conduct of development workings after the long face.

When filling cut rocks in the worked-out space from the separate excavation of coal and rock, the main requirements for the technological scheme are ensuring a clear interaction between the processes of excavation and stowing; minimum coal content in filling materials. To do this, the performance of filling equipment must correspond to the performance of the excavation complex, and the downtime of each of the links must have minimal impact on the performance of the other link.

When choosing technological schemes, it is also necessary to strive to create a unified technology that will develop seams without dangerous subsidence of the earth's surface, reuse development workings and provide small production wastes.

\section{Assessment of environmental efficiency of working coal seams with a stowing of the worked-out area}

To increase the environmental efficiency of the coal mining enterprise, it is recommended to introduce technological schemes of coal seams development with a stowing of the worked-out area. The results of expert assessment of environmental efficiency of the proposed technological solutions are given in Table 2.

Analysis of the data in Table 2 revealed that the application of the technology of stowing of the worked-out area will minimize the negative consequences of the operation of coal mining enterprises. At the same time, there will be a gradual reduction of the negative impacts of the company on almost all components of the environment. Early introduction of environmental technologies will reduce the negative consequences of the operation of the mining enterprise, and especially in the post-liquidation period. 
Table 2. Expert assessment of ecological efficiency of technologies application for a stowing of the worked-out area at the coal mining enterprises.

\begin{tabular}{|c|c|c|c|c|c|}
\hline \multirow{2}{*}{ Types of influence } & \multicolumn{5}{|c|}{ Objects of influence } \\
\hline & Atmosphere & Hydrosphere & Lithosphere & Soils & Biota \\
\hline $\begin{array}{l}\text { Decreased stability and } \\
\text { hardness of rocks }\end{array}$ & 0 & 1 & 1 & 1 & 1 \\
\hline $\begin{array}{l}\text { Deformation of the rock } \\
\text { mass }\end{array}$ & 0 & 1 & 1 & 1 & 2 \\
\hline $\begin{array}{l}\text { Subsidence of the earth's } \\
\text { surface }\end{array}$ & 0 & 1 & 1 & 1 & 2 \\
\hline $\begin{array}{l}\text { Water-saturation of the } \\
\text { rock mas }\end{array}$ & 0 & 2 & 1 & 1 & 1 \\
\hline $\begin{array}{l}\text { Violation of } \\
\text { hydrological regime }\end{array}$ & 0 & 2 & 1 & 1 & 2 \\
\hline Depletion of aquifers & 0 & 2 & 1 & 1 & 1 \\
\hline $\begin{array}{l}\text { Pollution of surface water } \\
\text { bodies }\end{array}$ & 0 & 2 & 1 & 1 & 2 \\
\hline Migration of pollutants & 1 & 1 & 1 & 1 & 1 \\
\hline $\begin{array}{l}\text { Mixing of mine waters } \\
\text { with drinking waters of } \\
\text { underground horizons }\end{array}$ & 0 & 2 & 1 & 1 & 2 \\
\hline $\begin{array}{l}\text { Flooding and waterlogging } \\
\text { of lands }\end{array}$ & 0 & 1 & 1 & 1 & 2 \\
\hline $\begin{array}{l}\begin{array}{l}\text { Allocation of land for } \\
\text { waste heaps }\end{array} \\
\end{array}$ & 1 & 1 & 2 & 2 & 2 \\
\hline $\begin{array}{l}\text { Deformation and } \\
\text { destruction of buildings } \\
\text { and infrastructure }\end{array}$ & 1 & 1 & 2 & 2 & 2 \\
\hline $\begin{array}{l}\text { Formation of explosive } \\
\text { methane-air mixtures }\end{array}$ & 2 & 1 & 0 & 1 & 2 \\
\hline $\begin{array}{l}\text { Emission of mine gases to } \\
\text { the earth's surface }\end{array}$ & 2 & 1 & 1 & 1 & 1 \\
\hline
\end{tabular}

\section{Conclusions}

As a result of the research, the following conclusions can be drawn:

1. The identification of environmental and man-made risks that occur at different stages of coal development, found that the highest levels of environmental risks occur during the deformation and subsidence of the under-mined rock mass and the earth's surface.

2. To prevent deformation of the earth's surface and damage to infrastructure, the possibility of using the technology of integrated stowing of the worked-out areas of mines is substantiated.

3. The use of stowing of the worked-out areas in coal mines will protect land, buildings and structures from under-mining; increasing the stability of the side rocks in the working space of the breakade faces; increasing the stability of development workings in order to reuse them; utilization of rock from carrying out development mine workings.

4. Timely implementation of environmental measures at coal mining enterprises will reduce the level of environmental hazards of coal mining processes. It should be noted that the implementation of the proposed measures will be effective only if they are implemented at the existing coal mining enterprise, and this will reduce the levels of environmental danger in the further elimination of unprofitable coal mines. 
This work was supported by the Ministry of Education and Science of Ukraine under the project "Substantiation of the newest technological solutions for the development of mineral deposits in the context of mining regions sustainable development".

\section{References}

1. Pivnyak, G. G., \& Shashenko, O. M. (2015). Innovations and safety for coal mines in Ukraine. Naukovyi Visnyk Natsionalnoho Hirnychoho Universytetu, (6), 118-121.

2. Sribna, Y., Trokhymets, O., Nosatov, I., \& Kriukova, I. (2019). The globalization of the world coal market - contradictions and trends. E3S Web of Conferences, (123), 01044. https://doi.org/10.1051/e3sconf/201912301044

3. Pivnyak, G., Bondarenko, V., \& Kovalevska, I. (Eds.). (2015). New Developments in Mining Engineering 2015. London, United Kingdom: CRC Press, Taylor \& Francis Group. https://doi.org/10.1201/b19901

4. Belov, O., Shustov, O., Adamchuk, A. \& Hladun, O. (2018). Complex processing of brown coal in Ukraine: history, experience, practice, prospects. Solid State Phenomena, (277), 251-268. doi:10.4028/www.scientific.net/SSP.277.251

5. Savchuk, V., Prykhodchenko, V., Buzylo, V., Prykhodchenko, D., \& Tykhonenko, V. (2013). Complex use of coal of Northern part of Donbass. Annual Scientific-Technical Collection Mining of Mineral Deposits, 185-191. https://doi.org/10.1201/b16354-34

6. Vambol, S., Vambol, V., Kondratenko, O., Suchikova, Y. \& Hurenko, O. (2017). Assessment of improvement of ecological safety of power plants by arranging the system of pollutant neutralization. Eastern-European Journal of Enterprise Technologies, 3(10(87)), 63-73. https://doi.org/10.15587/1729-4061.2017.102314

7. Shmandiy, V., Bezdeneznych, L., Kharlamova, O. at al (2017). Methods of salt content stabilization in circulating water supply systems. Chemistry \& Chemical Technology, 11(2), 242246. https://doi.org/10.23939/chcht11.02.242

8. Kharytonov M.M. \& Kroik A.A. (2011). Environmental Security of Solid Wastes in the Western Donbas Coal Mining Region, Ukraine. Environmental Security and Ecoterrorism, NATO Science for Peace and Security Series C: Environmental Security, H. Alpaset al. (eds.), 129-138. https://doi.org/10.1007/978-94-007-1235-5_10

9. Khomenko, O., Kononenko, M., Myronova, I., \& Savchenko, M. (2019). Application of the emulsion explosives in the tunnels construction. E3S Web of Conferences, (123), 01039. https://doi.org/10.1051/e3sconf/201912301039

10. Cherniaiev, O.V. (2017). Systematyzatsiia nerudnykh rodovyshch skelnykh korysnykh kopalyn dlia vdoskonalennia tekhnolohii yikh vidpratsiuvannia. Naukovyi Visnyk NHU, (5), 11-17.

11. Kolesnyk, V., Kulikova, D. \& Kovrov, S. (2013). In-stream settling tank for effective mine water clarification. Annual Scientific-Technical Collection - Mining of Mineral Deposits, 285-289. https://doi.org/10.1201/b16354-53

12. Shmandiy, V., Bezdeneznych, L., Kharlamova, O. et al. (2017). Methods of salt content stabilization in circulating water supply systems, Chemistry and Chemical Technology, 11(2), 242-246. https://doi.org/10.23939/chcht11.02.242

13. Zelenko, Y., Malovanyy, M., \& Tarasova, L. (2019). Optimization of heat-and-power plants water purification, Chemistry and Chemical Technology, 13(2), 218-223. https://doi.org/10.23939/chcht13.02.218

14. Adamenko, Y.O., Arkhypova, L.M., \& Mandryk, O.M. (2017). Territorial normative of quality of hydroecosystems of protected territories, Hydrobiological Journal, (53), 50-58. https://doi.org/10.1615/HydrobJ.v53.i2.50

15. Mandryk, O.M., Arkhypova, L.M., Pukish, A.V., Zelmanovych, A., \& Yakovlyuk, K. (2017). Theoretical and methodological foundations of sustainable development of Geosystems. IOP Conference Series: Materials Science and Engineering, (200), 012018 https://doi.org/10.1088/1757-899X/200/1/012018 
16. Golinko, V. I., Yavorskaya, E. A., Cheberyachko, Y. I., Cheberyachko, S. I. (2015). Analysis of protective value of dust-fighting respirators and its effect on dust burden of miners. Gornyi Zhurnal, 76-80. https://doi.org/10.17580/gzh.2016.03.16

17. Klimkina, I., Kharytonov, M., Zhukov, O. (2018). Trend analysis of water-soluble salts vertical migration in technogenic edaphotops of reclaimed mine dumps in Western Donbas (Ukraine). Environmental Research, Engineering and Management, 74(2), 82-93 https://doi.org/10.5755/j01.erem.74.2.19940

18. Vambol, S., Vambol, V., Sundararajan, M., \& Ansari, I. (2019). The nature and detection of unauthorized waste dump sites using remote sensing. Ecological Questions, 30(3)3). https://doi.org/10.12775/EQ.2019.018

19. Popovych, V., Kuzmenko, O., Voloshchyshyn, A., \& Petlovanyi, M. (2018). Influence of manmade edaphotopes of the spoil heap on biota. E3S Web of Conferences, (60), 00010. https://doi.org/10.1051/e3sconf/20186000010

20. Gomelya, M.D., Trus, I.M. \& Radovenchyk, I.V. (2014). Influence of stabilizing water treatment on weak acid cation exchange resin in acidic form on quality of mine water nanofiltration desalination. Naukovyi Visnyk Natsionalnoho Hirnychoho Universytetu, (5), 100-105.

21. Kvaterniuk, S., Pohrebennyk, V., Petruk, V., Kvaterniuk, O., \& Kochanek, A. (2018). Mathematical modeling of light scattering in natural water environments with phytoplankton particles, $18^{\text {th }}$ International Multidisciplinary Scientific GeoConference Surveying Geology and Mining Ecology Management, SGEM, 18(2.1), 545-552. https://doi.org/10.5593/sgem2018/2.1

22. Melnyk, L., Bessarab, O., Matko, S. \& Malovanyy, M. (2015). Adsorption of Heavy Metals Ions from Liquid Media by Palygorskite. Chemistry \& Chemical Technology, 9(4), 467-470. https://doi.org/10.23939/chcht09.04.467

23. Moshynsky, V. (2001). Modern water conditions in the northwest part of Ukraine: An analysis. Water Engineering and Management, 148(4), 22-26

24. Kolesnik, V.Ye., Fedotov, V.V. \& Buchavy, Yu.V. (2012). Generalized algorithm of diversification of waste rock dump handling technologies in coal mines. Naukovyi Visnyk Natsionalnoho Hirnychoho Universytetu, (4), 138-142.

25. Pivniak, H.H., Pilov, P.I., Pashkevych, M.S., \& Shashenko, D.O. (2012). Synchro-mining: Civilized solution of problems of mining regions' sustainable operation. Naukovyi Visnyk Natsionalnoho Hirnychoho Universytetu, (3), 131-138.

26. Litvinov, Y., Terekhov, Y., \& Fenenko, V. (2019). Improvement of open field development technology as a factor in the formation of quality and market value of reclaimed land. E3S Web of Conferences, (123), 01045. https://doi.org/10.1051/e3sconf/201912301045

27. Sobko B., Lozhnikov O., Levytskyi V., \& Skyba G. (2019). Conceptual development of the transition from drill and blast excavation to non-blasting methods for the preparation of mined rock in surface mining. Rudarsko Geolosko Naftni Zbornik, 34(3), 21-28. https://doi.org/10.17794/rgn.2019.3.3

28. Zadorozhnaya, G.A., Andrusevych, K.V., \& Zhukov, O.V. (2018). Soil heterogeneity after recultivation: ecological aspect. Folia Oecologica, 45: 46-52. https://doi.org/10.2478/foecol-2018$\underline{0005}$

29. Golovchenko, A. (2020). Some Aspects of the Control for the Radial Distribution of Burden Material and Gas Flow in the Blast Furnace. Energies, 13(4), 923. https://doi:10.3390/en13040923

30. Dychkovskyi, R.O. (2015). Forming the bilayer artificially created shell of georeactor in underground coal well gasification. Naukovyi Visnyk Natsionalnoho Hirnychoho Universytetu, (5), $37-42$

31. Falshtynskyi, V.S., Dychkovskyi, R.O., Lozynskyi, V.G., \& Saik, P.B. (2013). Determination of the Technological Parameters of Borehole Underground Coal Gasification for Thin Coal Seams. Journal of Sustainable Mining, 12(3), 8-16. https://doi.org/10.7424/jsm130302

32. Sobolev, V. (2020). Reasons for breaking of chemical bonds of gas molecules during movement of explosion products in cracks formed in rock mass. International Journal of Mining Science 
and Technology, 30(2), 265-269. https://doi.org/10.1016/j.ijmst.2020.01.002

33. Dychkovskyi, R.O. (2015). Determination of the rock subsidence spacing in the well underground coal gasification. Naukovyi Visnyk Natsionalnoho Hirnychoho Universytetu, (6), 30-36.

34. Lozynskyi, V.H., Dychkovskyi, R.O., Falshtynskyi, V.S., \& Saik, P.B. (2015). Eksperymentalni doslidzhennia vplyvu perekhodu dyziunktyvnoho heolohichnoho porushennia na temperaturnyi rezhym pidzemnoho hazoheneratora. Naukovyi Visnyk NHU, (4), 22-28.

35. Soboliev, V., Bilan, N., \& Samovik, D. (2013). Magnetic stimulation of transformations in coal. Annual Scientific-Technical Collection - Mining of Mineral Deposits, 221-225. https://doi.org/10.1201/b16354-41

36. Khomenko, O., Kononenko, M., \& Myronova, I. (2013). Blasting works technology to decrease an emission of harmful matters into the mine atmosphere. Annual Scientific-Technical Colletion - Mining of Mineral Deposit, 231-235. https://doi.org/10.1201/b16354-43

37. Bondarenko, V., Kovalevs'ka, I., Svystun, R., \& Cherednichenko, Y. (2013). Optimal parameters of wall bolts computation in the united bearing system of extraction workings framebolt support. Annual Scientific-Technical Collection - Mining of Mineral Deposits 2013, 5-9. https://doi.org/10.1201/b16354-3

38. Bondarenko, V., Symanovych, G., \& Koval, O. (2012). The mechanism of over-coal thin-layered massif deformation of weak rocks in a longwall. Geomechanical Processes During Underground Mining, 41-44. https://doi.org/10.1201/b13157-8

39. Kolosov, D., Bilous, O., Tantsura, H., \& Onyshchenko, S. (2018). Stress-strain state of a flat tractive-bearing element of a lifting and transporting machine at operational changes of its parameters. Solid State Phenomena, (277), 188-201. https://doi.org/10.4028/www.scientific.net/ssp.277.188

40. Belmas, I., \& Kolosov, D. (2011). The stress-strain state of the stepped rubber-rope cable in bobbin of winding. Technical and Geoinformational Systems in Mining, 211-214. https://doi.org/10.1201/b11586-35

41. Law, B.E., Ulmishek, G.F., Clayton, J.L., Kabyshev, B.P., Pashova, N.T., \& Krivosheya, V.A. (1998). Basin-centered gas evaluated in Dnieper-Donets basin, Donbas foldbelt, Ukraine. Oil and Gas Journal, 96(47), 74-78.

42. Buzylo V., Yavorsk'yy, A. Yavorsk'yy. V. (2012). Analysis of stress-strain state of rock mass while mining chain pillars by chambers. Geomechanical Processes during Underground Mining, 95-98. https://doi.org/10.1201/b13157-16

43. Shashenko, O.M., \& Kovrov, O.S. (2016). Comparative analysis of two failure criteria for rocks and massifs. Naukovyi Visnyk Natsionalnoho Hirnychoho Universytetu, (6), 54-59.

44. Popovych, V., \& Voloshchyshyn, A. (2019). Features of temperature and humidity conditions of extinguishing waste heaps of coal mines in spring. News of National Academy of Sciences of the Republic of Kazakhstan, 4(436), 230-237. https://doi.org/10.32014/2019.2518-170x.118

45. Buzylo, V., Savelieva, T., \& Saveliev, V. (2012). Study of rock displacement with the help of equivalent materials using room-and-pillar mining method. Geomechanical Processes During Underground Mining, 29-34. https://doi.org/10.1201/b13157-6

46. Babets, D.V., Sdvyzhkova, O.O., Larionov, M.H., Tereshchuk, R.M. (2017). Otsinka stiikosti masyvu hirskykh porid, shcho bazuietsia na ymovirnisnomu pidkhodi ta reitynhovykh klasyfikatsiiakh. Naukovyi visnyk NHU, (2), 58-64.

47. Vladyko, O., Kononenko, M., \& Khomenko, O. (2012). Imitating modeling stability of mine workings. Geomechanical Processes During Underground Mining, 147-150. https://doi.org/10.1201/b13157-26

48. Mambetov, S.A., Mambetov, A.S., \& Abdiev, A.R. (2002). Zonal and step-by-step evaluation of the stressed-strained state of Tyan'-Shan' rock massif. Gornyi Zhurnal, (10), 57-62.

49. Buzylo, V., Pavlychenko, A., Borysovska, O., \& Saveliev, D. (2019). Investigation of processes of rocks deformation and the earth's surface subsidence during underground coal mining. E3S Web of Conferences, (123), 01050. https://doi.org/10.1051/e3sconf/201912301050 
50. Buzylo, V., Pavlychenko, A., Savelieva, T., Borysovska, O. (2018). Ecological aspects of managing the stressed-deformed state of the mountain massif during the development of multiple coal layers. E3S Web of Conferences, (60), 00013. https://doi.org/10.1051/e3sconf/20186000013

51. Borisovskaya, Ye.A., \& Fedotov, V.V. (2014). Improvement of the method of danger class definition of coal-mining solid wastes, Naukovyi Visnyk Natsionalnoho Hirnychoho Universytetu, (3), 130-137.

52. Halysh, V., Trus, I., Gomelya, M. at al (2020). Utilization of modified biosorbents based on walnut shells in the processes of wastewater treatment from heavy metal ions. Journal of Ecological Engineering, 21(4), 128-133. https://doi.org/10.12911/22998993/119809

53. Ovchynnikova, O., Dupliak, O., \& Khan, O. (2020). Modelling and forecasting of the region's environmental indicators. E3S Web of Conferences, (166), 13004. https://doi.org/10.1051/e3sconf/202016613004

54. Kharytonov, M.M., Stankevich, S.A., Titarenko, O.V. at al (2020). Geostatistical and geospatial assessment of soil pollution with heavy metals in Pavlograd city (Ukraine). Ecological Questions, 31(2), 47-61. http://dx.doi.org/10.12775/EQ.2020.013

55. Tregub, M., \& Trehub, Y. (2015). Substantiation of land management methods of industrial cities. New Developments in Mining Engineering, 449-452. https://doi.org/10.1201/b19901-79

56. Malovanyy, M., Lyashok, Y., Podkopayev, S., at al (2020). Environmental technologies for use of coal mining and chemical industry wastes. Journal of Ecological Engineering, 21(2), 85-93. https://doi.org/10.12911/22998993/116339

57. Gorova, A., Pavlychenko, A., \& Borysovs'Ka, O. (2013). The study of ecological state of waste disposal areas of energy and mining companies. Annual Scientific-Technical Colletion - Mining of Mineral Deposits, 169-172. https://doi.org/10.1201/b16354-29

58. Gorova, A., Pavlychenko, A., Kulyna, S., \& Shkremetko, O. (2012). Ecological problems of post-industrial mining areas. Geomechanical Processes During Underground Mining, 35-40. https://doi.org/10.1201/b13157-7

59. Abdykaparov, C.M., \& Abdiev, A.R. (2002). State and prospects of the development the brown coal deposit in Kara-Keche. Gornyi Zhurnal, (10), 16-19. 